\title{
Sistem Pakar Diagnosa Kelainan Sistem Ortopedi pada Manusia dengan Metode Forward Chaining dan Dempster Shafer
}

\author{
(Expert System for Diagnosing Abnormalities of Human Orthopedics System using \\ forward chaining and Dempster Shafer Method)
}

\author{
Nurhaini Rahmawati, Fitri bimantoro* \\ Program Studi Teknik Informatika, Fakultas Teknik, Universitas Mataram \\ Jl. Majapahit 62, Mataram, Lombok NTB, INDONESIA \\ Email: nurhainir20@gmail.com, bimo@unram.ac.id
}

"Penulis Korespondensi

\begin{abstract}
The bones and skeleton are very important parts of orthopedics and are the most vulnerable parts of the body. One of the obstacles in the diagnosis of orthopedic disorders is the distance from the hospital and the few orthopedic doctors. This study developed an expert system that runs on an Android-based smartphone to diagnose 13 types of abnormalities in the orthopedic system with 92 symptom input based on the knowledge of 3 experts using the forward chaining and dempster shafer methods to obtain conclusions about the type of orthopedic disorder suffered. Based on the test results with theoretical calculations, it is found that the system calculation results are in accordance with the results of manual calculations. In testing the accuracy of the system, from 30 examples of cases tested on 3 experts, the accuracy value was obtained based on the average expert weight of $\mathbf{8 1 . 1 1 \%}$, the weight of each expert in sequence is $80.00 \%$ for expert $1,83.33 \%$ for expert 2 , and $73.33 \%$ for expert 3 , where this accuracy value shows that the performance of the dempster shafer method in diagnosing orthopedic disorders is good and it can be said that the dempster shafer method suitable to be applied in cases of orthopedic disorders. The MOS (Mean Opinion Score) test on 30 respondents resulted in an MOS value of $\mathbf{4 . 4 5}$ from a scale of 5 which indicates that the system is feasible to use and is categorized into a good system.
\end{abstract}

Key words: Expert system, orthopedics, forward chaining, Dempster Shafer, android

\section{PENDAHULUAN}

Tulang dan kerangka merupakan bagian yang sangat penting di dalam bagian ortopedi, tidak hanya sebagai penguat tubuh tetapi juga merupakan bagian dari susunan sendi, sebagai pelindung tubuh, tempat melekatnya bagian ujung otot yang melekat pada tulang dan otot-otot yang menggerakan kerangka tubuh [1]. Tulang, Otot dan Sendi (TOS) merupakan bagian tubuh yang sangat rentan mengalami gangguan.

Beberapa cara yang dapat digunakan untuk mengenali kelainan ortopedi, salah satunya yakni dengan melakukan konsultasi dengan spesialis ortopedi yang diawali dengan proses wawancara singkat. Dalam beberapa kasus harus dilakukan tes laboratorium dan pencitraan untuk mengonfirmasi diagnosis. Konsultasi disarankan ketika seseorang mengalami gejala seperti nyeri otot atau sendi kronis, kerusakan sendi, cedera tulang, nyeri punggung dan lainnya [2].

Pada kenyataanya konsultasi tidak selalu bisa dilakukan karena beberapa kendala, salah satu diantaranya adalah karena dokter ahli tulang yang jumlahnya sedikit serta mahalnya biaya konsultasi dengan dokter menjadikan seseorang malas berkonsultasi ke dokter [3]. Hal ini juga mengakibatkan masyarakat lebih memilih pengobatanpengobatan tradisional seperti mengunjungi penyedia layanan terapi pijat/urut. Oleh karena itu, diperlukan sebuah sistem pakar yang mengadopsi pengetahuan pakar khusus di bidang ortopedi yang dapat membantu masyarakat untuk melakukan konsultasi tanpa perlu mengeluarkan biaya sekaligus menjadi solusi kurangnya jumlah dokter spesialis ortopedi. Terdapat beberapa metode yang digunakan dalam sistem pakar untuk perhitungan ketidakpastian, diantaranya adalah metode Dempster Shafer [4] dan dengan mesin inferensi forward chaining.

Dempster shafer merupakan teori matematika untuk pembuktian berdasarkan fungsi kepercayaan untuk mengkombinasikan informasi terpisah, sedangkan forward chaining merupakan konsep umum pemikiran yang berfokus pada data yang diketahui [5]. Alasan menggunakan metode Dempster Shafer (DS) yaitu karena metode ini cocok digunakan untuk mengukur ketidakpastian dan tingkat keyakinan pakar. Perhitungan yang dilakukan pada metode ini juga dirasa mudah dan sederhana karena hanya menghitung probabilitas penyakit dari setiap gejala yang ada berdasarkan bobot yang diberikan oleh pakar. Alasan dipilihnya mesin inferensi forward chaining sebagai pencarian jalur penalaran yaitu karena metode ini cocok untuk sistem yang memiliki banyak hipotesa keluaran dan tepat digunakan jika faktafakta yang ada lebih banyak dibandingkan dengan kesimpulan yang akan dicari. 


\section{TINJAUAN PUSTAKa DAN DASAR TEORI}

\section{A. Tinjauan Pustaka}

Terdapat beberapa penelitian yang dijadikan sumber rujukan dalam penelitian ini. Dengan menggunakan Teorema Bayes yang mendiagnosa 8 penyakit dan 35 gejala memperoleh akurasi $62,07 \%$ dan menyarankan penambahan daftar penyakit dan gejala serta sistem dibangun berbasis android [6]. Penelitian dengan metode Jaringan Syaraf Tiruan Backpropagation yang melibatkan 1 orang pakar dengan data 10 penyakit dan 42 gejala dengan akurasi tertinggi 90\% menyarankan untuk dilakukannya penelitian lebih lanjut dengan jaringan syaraf tiruan yang berbeda dengan menambah jumlah dataset pelatihan dan dikembangkan dengan aplikasi berbasis website atau mobile [7], sedangkan dengan metode Forward Chaining untuk mendiagnosa Osteoporosis memperoleh akurasi sebesar $83,3 \%$ dan menyarankan penambahan metode lain untuk meningkatkan akurasi [8].

Penelitian yang menggunakan metode Certainty Factor, diantaranya untuk mendiagnosis penyakit Artritis Gout, Artritis Reumatoid dan Osteoartritis dengan ditambahkan metode Forward Chaining memperoleh nilai Certainty Factor terbesar 0.984 [3], untuk mendeteksi risiko Osteoporosis dan Osteoartritis yang melibatkan dua orang pakar dari rumah sakit yang berbeda memperoleh rata-rata akurasi mencapai $80 \%$ dari kedua pakar [9].

Selain beberapa penelitian di atas, terdapat beberapa penelitian terdahulu yang meneliti tentang penggunaan metode Dempster Shafer dalam sistem pakar. Terdapat pula penelitian yang membandingan metode Dempster Shafer dengan metode lain.

Penelitian sistem pakar dengan metode Dempster Shafer untuk mendiagnosa infeksi penyakit tropis dengan data sebanyak 9 jenis penyakit dan pengujian sistem dengan menggunakan 104 data sampel rekam medis memperoleh akurasi 94.23\% [10]. Penelitian sistem pakar untuk mendiagnosa penyakit tanaman jeruk memperoleh akurasi sebesar $90 \%$ dari pengujian 30 data uji [11] dan akurasi sebesar 95\% dalam mendiagnosa gangguan mental pada anak [4].

Berdasarkan beberapa tinjauan pustaka dari penelitian terdahulu yang telah dijabarkan, maka penulis akan membangun sistem pakar yang dapat mendiagnosa kelainan ortopedi pada manusia dengan metode forward chaining sebagai mesin inferensi karena dinilai dapat menyelesaikan kasus dengan banyak potongan informasi yang saling terkait yang memiliki banyak hipotesa keluaran, dan menggunakan metode penarikan kesimpulan dempster shafer untuk mendapatkan nilai akhir kesimpulan yang tinggi sebagaimana pada penelitian sebelumnya.

\section{B. Dasar Teori}

\section{B.1. Sistem Pakar}

Sistem pakar merupakan aplikasi berbasis komputer yang mengadopsi pemahaman pakar dan digunakan untuk menyelesaikan masalah yang tidak bisa diselesaikan oleh orang awam [1] . Sistem pakar terdiri dari dua lingkungan yaitu lingkungan pengembang dan lingkungan konsultasi [12].

\section{B.2. Metode Forward Chaining}

Metode forward chaining merupakan salah satu metode penalaran dalam sistem pakar yang mulai bekerja dengan data yang tersedia dan menggunakan aturan inferensi untuk mendapatkan data yang lain sampai kesimpulan didapatkan [5]. Penelusuran dimulai dari fakta yang ada yakni berupa data gejala-gejala penyakit lalu bergerak maju melalui rules yang ada untuk menuju kesimpulan berupa penyakit yang dialami. Gambaran dari penelusuran yang dilakukan metode forward chaining dapat dilihat pada Gambar 1.

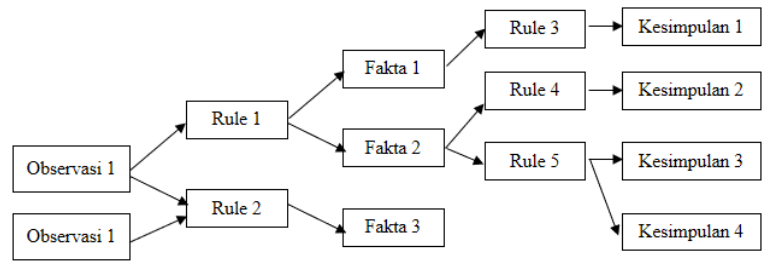

Gambar 1. Alur penelusuran metode forward chaining

\section{B.3. Dempster Shafer}

Merupakan salah satu metode sistem pakar dengan teori matematika untuk membuktikan suatu infoemasi berdasarkan nilai belief. Secara umum teori DempsterShafer ditulis dalam suatu interval: [Belief, Plausibility]. Belief (Bel) adalah ukuran kekuatan evidence dalam mendukung suatu himpunan proposisi. Jika bernilai 0 maka mengindikasikan bahwa tidak ada evidence, dan jika $m$ bernilai 1 menunjukkan adanya kepastian [10]. Plausibility $(P l s)$ adalah ukuran ketidakpercayaan atau ketidakpastian terhadap suatu evidence. Plausibility ( $P l s)$ akan mengurangi tingkat kepastian dari evidence. Plausibility bernilai 0 sampai 1. Jika yakin akan X', maka dapat dikatakan bahwa $\operatorname{Bel}\left(\mathrm{X}^{\prime}\right)=1$, sehingga nilai dari $\operatorname{Pl}(\mathrm{X})=0$. Fungsi Belief diformulasikan seperti pada Persamaan (1) dan fungsi Plausibility diformulasikan seperti pada Persamaan (2) [4].

$$
\begin{gathered}
\operatorname{Bel}(\mathrm{X})=\sum_{\mathrm{Y} \subseteq \mathrm{X}} \mathrm{m}_{1}(\mathrm{X}) \\
\operatorname{Pls}(\mathrm{X})=1-\operatorname{Bel}(\mathrm{X}) \\
\operatorname{Pls}(\mathrm{X})=1-\sum_{\mathrm{Y} \subseteq \mathrm{X}} \mathrm{m}_{1}(\mathrm{X})
\end{gathered}
$$

Pada teori Dempter Shafer semesta pembicaraan dari sekumpulan hipotesis sering disebut environment, dinotasikan dengan simbol $\Theta$ seperti pada Persamaan (3).

$$
(\Theta)=\left\{\theta_{1}, \theta_{2}, \ldots \theta n\right\}
$$

Fungsi kombinasi $m_{1}$ dan $m_{2}$ sebagai $m_{3}$ dibentuk dengan rumus pada Persamaan (4) [10]:

$$
m_{3}(Z)=\frac{\sum_{X \cap Y=Z} \quad m_{1}(X) \cdot m_{2}(Y)}{1-\sum_{X \cap Y=\varnothing} m_{1}(X) \cdot m_{2}(Y)}
$$


Hasil akhir dari nilai kepercayaan dihitung dengan rumus pada Persamaan (5) [4]:

nilai akhir kepercayaan pernyataan $(\mathrm{x})=$

(nilai jawaban responden $1+\cdots+$ nilai jawaban responden $n$ ) jumlah responden

\section{B.4. Kelainan Ortopedi}

Terdapat 13 jenis kelainan ortopedi yang umumnya dialami oleh manusia yang menjadi objek dalam penelitian ini. Data 13 penyakit tersebut diperoleh dari hasil wawancara bersama pakar utama selama proses penelitian dan merupakan jenis kelainan yang sering dan umum diderita oleh masyarakat.

1. Fraktur tertutup, merupakan jenis fraktur yang tidak berhubungan dengan dunia luar dan tidak terdapat luka [3].

2. Fraktur terbuka, merupakan jenis fraktur yang berhubungan dengan dunia luar melalui kulit [3].

3. Spondilitis TB, merupakan penyakit yang disebabkan oleh kuman tuberkulosis dimana pada penyakit ini terjadi peradangan pada ruas tulang belakang [13].

4. $\quad$ Osteomielitis Kronis, merupakan infeksi tulang yang menyebabkan kerusakan tulang dan pembentukan tulang baru. Osteomielitis ada dua macam, yaitu osteomielitis kronis dan akut [3].

5. Osteoarthritis, merupakan penyakit yang menyerang sendi besar dan terkadang mengenai sendi-sendi kecil pada tangan dan kaki [9].

6. Osteopororsis, merupakan kelainan yang disebabkan penurunan massa tulang dan kebiasaan mengkonsumsi obat-obatan dalam jangka panjang yang dapat merusak tulang seperti obat anti kejang dan hormone tiroid yang diresepkan dalam dosis tinggi [9].

7. Gout arthritis, merupakan kelainan metabolik yang terjadi sebagai akibat dari hyperuricemia yang berlangsung lama yang disebabkan oleh penumpukan purin atau reaksi asam urat yang kurang dari ginjal[3].

8. Rheumatoid arthritis, merupakan penyakit yang ditandai dengan terdapatnya sinovitis erosive simetrik terutama pada jaringan persendian dan sering melibatkan organ tubuh lainnya [3].

9. Osteosarcoma, merupakan jenis kanker tulang yang umumnya terjadi pada anak-anak dan remaja dan cendrung dialami oleh pria. Osteosarcoma umumnya adalah tumor yang agresif [14].

10. Osteochondroma, merupakan tumor jinak pada tulang berupa penonjolan tulang yang dilingkupi lapisan tulang rawan [15].

11. Ricketsia, merupakan kelainan tulang yang disebabkan karena kekurangan vitamin D, kalsium dan fosfat dan menyerang tulang lengan, kaki, panggul dan tulang belakang.

12. Scoliosis terbagi menjadi dua yaitu non struktural dan struktural. Gejala scoliosis biasanya dirasakan saat kondisi parah dan pada kondisi ini dirasakan adanya ketidakseimbangan posisi thorax, scapula yang menonjol pada satu sisi, bahu tidak horizontal [16].

\section{B.5. Android}

Android merupakan sistem operasi berbasis linux untuk telepon seluler smartphone dan tablet. Android juga menyediakan platform terbuka bagi pengembang untuk membuat aplikasi sendiri. Antarmuka pengguna android umumnya menggunakan layar sentuh dengan tindakan menggeser, mengetuk dan mencubit.

\section{Metodologi PenElitian}

\section{A. Alat dan Bahan}

Alat dan bahan yang digunakan selama proses pembangunan system pakar kelainan ortopedi meliputi:

1. Toshiba Satellite processor Intel inside core i5 dan memori RAM 8 GB.

2. Smartphone Android (Huawei Y6II Marsmellow 6.0 version)

3. Sistem Operasi Windows 10 Pro-64-bit

4. Microsoft Office 2010

5. Android Studio

6. Literatur-literatur pendukung tentang deskrispsi penyakit tulang, otot dan sendi.

7. Data gejala dan jenis-jenis penyakit tulang, otot dan sendi.

8. Data relasi atau bobot antar gejala dan penyakit

9. Data solusi pencegahan kelainan ortopedi

\section{B. Proses Penelitian}

Penelitian sistem pakar diagnosa penyakit tulang, otot dan sendi ini dilakukan melalui beberapa tahapan seperti yang disajikan dalam diagram alir penelitian pada Gambar 2.

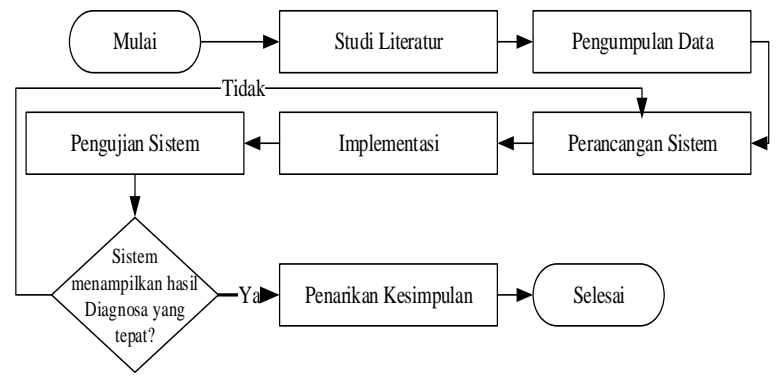

Gambar 2. Diagram alir proses penelitian

Proses penelitian sistem pakar diagnosa penyakit TOS berdasarkan Gambar 2 terdiri atas beberapa tahapan diantaranya:

\section{B.1. Studi Literatur}

Merupakan proses mengumpulkan sumber-sumber yang terkait dengan sistem pakar, kelainan ortopedi pada manusia, serta penerapan metode forward chaining dan Dempster Shafer melalui jurnal ilmiah, skripsi, paper dan sumber lainnya untuk melihat kekurangan serta kelebihan yang ada sebagai acuan dalam penelitian yang akan dilakukan. 


\section{B.2. Pengumpulan Data}

Proses pengumpulan data dilakukan melalui wawancara dengan pakar sebelum dan selama membangun sistem. Dilakukan sebelum membangun sistem tujuannya yaitu untuk mengetahui jenis kelainan ortopedi yang paling sering menyerang masyarakat, sedangkan selama membangun sistem untuk melengkapi data penelitian. Pakar dalam penelitian ini yaitu dokter spesialis ortopedi yang berjumlah 3 orang.

\section{B.3. Perancangan Sistem}

Perancangan sistem terdiri dari perancangan arsitektur dan perancangan antarmuka sistem. Sistem pakar terdiri dari dua bagian utama, yaitu lingkungan pengembangan dipakai pengembang untuk mengenalkan pengetahuan kepada knowledge base dan lingkungan konsultasi dipakai oleh user untuk mendapatkan suatu pengetahuan keahlian pakar. Ilustrasi arsitektur sistem pakar diagnosa kelainan ortopedi yang akan dijelaskan pada Gambar 3 .

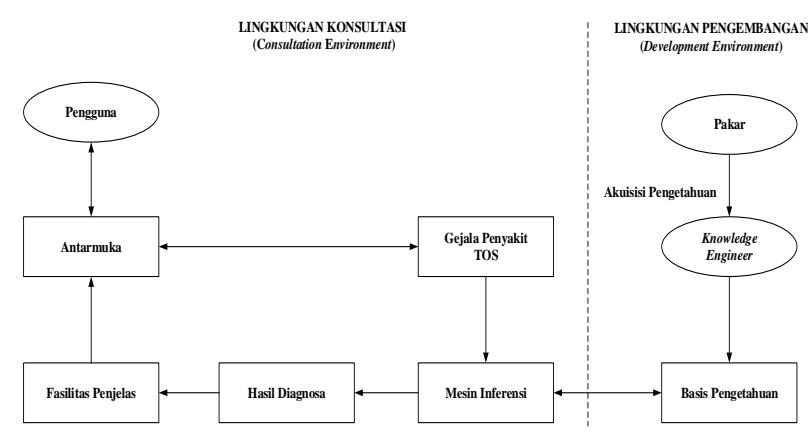

Gambar 3. Arsitektur sistem pakar diagnosa kelainan sistem ortopedi[17]

Elemen-elemen dari arsitektur sistem pakar diagnosa kelainan sistem ortopedi pada manusia pada Gambar 3 terdiri atas:

1. Pengguna sistem, yaitu masyarakat umum sebagai pengguna aplikasi dan melakukan konsultasi penyakit serta mendapatkan informasi solusinya.

2. Antarmuka, yaitu mekanisme untuk berkomunikasi antara pengguna dan sistem yang ditampilkan berupa aplikasi Android.

3. Gejala Penyakit TOS, digunakan sebagai masukan pada sistem untuk diproses untuk kemudian dikeluarkan output berupa hasil diagnosa penyakit yang diderita.

4. Pakar, merupakan salah satu komponen dalam sistem pakar yang memiliki peranan penting, karena merupakan sumber pengetahuan yang akan digunakan dalam sistem. Pakar pada penelitian ini yaitu dokter spesialis ortopedi yang berjumlah 3 orang pakar.

5. Akuisisi Pengetahuan adalah akumulasi, transfer dan transformasi keahlian dalam menyelesaikan masalah ke dalam program komputer dari sumber pengetahuan.

6. Knowledge Engineer, yaitu berperan sebagai penerjemah pengetahuan pakar ke dalam basis pengetahuan untuk dijadikan dasar pembentukan aturan pada sistem yang akan dibangun.
7. Basis Pengetahuan, merupakan kumpulan pengetahuan yang diperoleh dari pakar maupun sumber lain.

8. Mesin Inferensi, yaitu bagian yang berperan dalam proses menghasilkan informasi berdasarkan data fakta yang ada atau proses penalaran. Mesin inferensi yang digunakan pada sistem ini adalah forward chaining.

9. Hasil Diagnosa, merupakan hasil akhir yang diperoleh sistem berdasarkan masukan dari pengguna yang telah diproses oleh sistem berupa nama penyakit TOS yang diderita, persentase nilai kepercayaan sistem terhadap penyakit serta solusi penanganan dan pencegahan.

10. Fasilitas Penjelas, yaitu berfungsi memberikan penjelasan kepada pengguna mengenai proses pengambilan keputusan oleh sistem.

\section{B.4. Implementasi}

Proses pengimplementasian rancangan sistem yang telah dibuat ke dalam sebuah program. Pada bagian implementasi sistem ini akan membahas tentang antar muka dari sistem yang dibangun beserta cara kerja sistem.

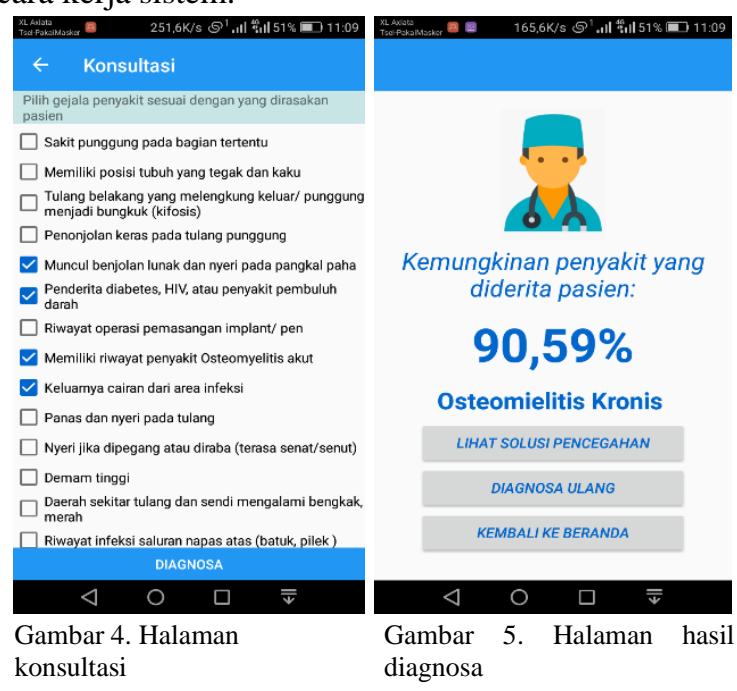

Halaman konsultasi pada Gambar 4 merupakan halaman yang akan muncul ketika pengguna memilih menu konsultasi pada halaman beranda. Pada halaman ini akan dimunculkan beberapa gejala yang tersimpan pada sistem untuk dipilih oleh pengguna berdasarkan yang dirasakan. Setelah selesai memilih gejala maka pengguna dapat menekan tombol diagnosa pada bagian bawah halaman untuk mengetahui hasil diagnosa.

Gambar 5 merupakan halaman yang akan muncul ketika pengguna menekan tombol diagnosa pada Gambar 4. Pada halaman ini akan ditampilkan hasil diagnosa berdasarkan gejala yang telah dipilih pengguna sebelumnya. Hasil diagnosa yang ditampilkan meliputi persentase serta nama dari kemungkinan penyakit yang diderita beserta gejalagejala yang dipilih sebelumnya.

\section{B.5. Pengujian Sistem}

Dilakukan untuk mengetahui kelayakan sistem yang dibuat serta kesesuaian hasil yang diberikan sistem. 
Pengujian yang dilakukan meliputi pengujian akurasi sistem, pengujian blackbox, pengujian MOS (Mean Opinion Score) serta pengujian dengan "perhitungan teoritis".

\section{B.6. Penarikan Kesimpulan}

Kesimpulan diperoleh berdasarkan hasil pengujian sistem dan kesesuaian hasil dari sistem yang dibangun dengan tujuan penelitian serta informasi yang dihasilkan sesuai dengan kebutuhan pengguna. Jika sistem menampilkan hasil diagnosa yang tepat yakni telah memenuhi pengujian akurasi dan perhitungan manual, maka penarikan kesimpulan data dilakukan dan sebaliknya.

\section{Nilai Belief Gejala Terhadap Suatu Penyakit}

Dalam proses perhitungan nilai kepastian (densitas) suatu diagnosa, diperlukan nilai belief (bobot) setiap gejala kelainan ortopedi yang diperoleh berdasarkan pada pengalaman pakar dalam mendiagnosa pasien, dimana pada metode Dempster Shafer bobot tersebut berada pada rentang 0 sampai 1 . Semakin tinggi keyakinan seorang pakar terhadap suatu gejala, maka akan semakin tinggi bobot yang diberikan.

\section{HASIL DAN PEMBAHASAN}

\section{A. Teknik Pengujian Sistem}

Pengujian sistem dilakukan untuk mengetahui kelayakan sistem berdasarkan hasil yang diperoleh dan kesesuaian dengan tujuan pembangunan sistem.

\section{A.1. Pengujian Black Box}

Fungsionalitas sistem pakar diagnosa kelainan sistem ortopedi pada manusia dengan metode Forward Chaining dan Dempster Shafer telah berjalan sesuai dengan fungsinya yang ditunjukkan oleh semua fungsionalitas yang diujikan kepada perwakilan 5 orang responden dari mahasiswa informatika sebagai pengguna android telah berjalan sebagaimana mestinya atau sesuai dengan rancangan. Pengujian bersama 5 orang mahasiswa informatika ditujukan karena selain menjadi pengguna android, mereka memiliki pengetahuan tentang sistem, dari segi fungsionalitas maupun user interface-nya, sehingga bisa dilakukan diskusi bersama selama pengujian jika terdapat kekurangan atau kekeliruan.

\section{A.2. Pengujian dengan Perhitungan Teoritis}

Misalkan diketahui pasien mengalami gejala seperti pada Tabel I.

TABEL I. GEJALA YANG DiRASAKAN

\begin{tabular}{|c|c|c|}
\hline $\begin{array}{r}\text { Gejala } \\
\end{array}$ & Nama Penyakit & Bobot \\
\hline \multirow[t]{3}{*}{ Nyeri jika digerakkan } & (P1) Patah tulang tertutup & 1 \\
\hline & (P6) Osteoarthritis & 0.7 \\
\hline & (P8) Gout arthritis & 0.7 \\
\hline \multirow{2}{*}{$\begin{array}{l}\text { Memiliki riwayat terjatuh atau pernah } \\
\text { mengalami kecelakaan }\end{array}$} & (P1) Patah tulang tertutup & 1 \\
\hline & (P2) Patah tulang terbuka & 1 \\
\hline \multirow{2}{*}{$\begin{array}{l}\text { Perubahan bentuk tulang pada area patah } \\
\text { tulang }\end{array}$} & (P1) Patah tulang tertutup & 0.8 \\
\hline & (P2) Patah tulang terbuka & 0.8 \\
\hline $\begin{array}{l}\text { Tidak ada tulang yang menonjol atau } \\
\text { tidak ada luka terbuka pada kulit }\end{array}$ & (P1) Patah tulang tertutup & 0.8 \\
\hline
\end{tabular}

Pada Tabel I dapat dilihat bahwa terdapat 4 gejala kelainan ortopedi yang dialami pasien. Setelah gejala tersebut diketahui, selanjutnya mesin inferensi yakni forward chaining mulai bekerja melakukan proses penalaran yakni dengan mencari tahu kemungkinan penyakit yang bisa terjadi dari setiap gejala yang dipilih, beserta bobot dari masing-masing gejala pada setiap penyakit berdasarkan basis pengetahuan yang tersimpan. Misalnya gejala 1 yakni nyeri jika digerakkan. Gejala 1 memiliki kemungkinan penyakit patah tulang tertutup, osteoarthritis dan gout arthritis dengan bobot masingmasing sebesar 1, 0.7 dan 0.7 begitu seterusnya untuk gejala 2, 3 dan 4. Setelah diketahui penyakit dan bobot dari masing-masing gejala pada setiap penyakit, selanjutnya dilakukan proses perhitungan dengan metode Dempster Shafer di mana setiap gejala dihitung dengan menggunakan rumus pada Persamaan (1), (2) dan (4) berdasarkan bobot masing-masing gejala untuk memperoleh kesimpulan hasil diagnosa berupa penyakit yang diderita beserta persentase kemungkinan terjadinya penyakit. Berikut proses perhitungan dengan menggunakan metode Dempster Shafer untuk setiap gejala.

a. Gejala 1: Nyeri jika digerakkan

$$
\begin{aligned}
& m_{1}\{\mathrm{P} 1, \mathrm{P} 6, \mathrm{P} 8\}=\frac{1+0.7+0.7}{3}=0.8 \\
& m_{1}\{\theta\}=1-0.8=0.2
\end{aligned}
$$

b. Gejala 2: Memiliki riwayat terjatuh atau pernah mengalami kecelakaan

$$
\begin{aligned}
& m_{2}\{\mathrm{P} 1, \mathrm{P} 2\}=\frac{1+1}{2}=1 \\
& m_{2}\{\theta\}=1-1=0
\end{aligned}
$$

Berdasarkan kedua perhitungan di atas, diperoleh kombinasi $m_{1}$ dan $m_{2}$ seperti pada Tabel II.

TABEL II. ATURAN KOMBINASI $m_{3}$ UNTUK CONTOH PERHITUNGAN TEORITIS

\begin{tabular}{|c|l|l|}
\hline \multirow{2}{*}{$m_{1}$} & \multicolumn{2}{|c|}{$m_{2}$} \\
\cline { 2 - 3 } & $m_{2}\{\mathrm{P} 1, \mathrm{P} 2\}=1$ & $m_{2}\{\Theta\}=0$ \\
\hline$m_{1}\{\mathrm{P} 1, \mathrm{P} 6, \mathrm{P} 8\}=0.8$ & $\{\mathrm{P} 1\}=0.8 \times 1=0.8$ & $\{\mathrm{P} 1, \mathrm{P} 6, \mathrm{P} 8\}=0.8 \times 0=0$ \\
\hline$m_{1}\{\Theta\}=1-1=0.2$ & $\{\mathrm{P} 1, \mathrm{P} 2\}=0.2 \times 1=0.2$ & $\{\Theta\}=0.2 \times 0=0$ \\
\hline
\end{tabular}

Sehingga dapat dihitung nilai densitas baru $\mathrm{m}_{3}$ :

$$
\begin{aligned}
& m_{3}\{\mathrm{P} 1\}=\frac{0.8}{1-0}=0.8 \\
& m_{3}\{\mathrm{P} 1, \mathrm{P} 2\}=\frac{0.2}{1-0}=0.2 \\
& m_{3}\{\mathrm{P} 1, \mathrm{P} 6, \mathrm{P} 8\}=0 \\
& m_{3}\{\theta\}=0
\end{aligned}
$$

c. Gejala 3: Perubahan bentuk tulang pada area patah tulang

$$
\begin{aligned}
& m_{4}\{\mathrm{P} 1, \mathrm{P} 2\}=\frac{0.8+0.8}{2}=0.8 \\
& m_{4}\{\theta\}=1-0.8=0.2
\end{aligned}
$$

TABEL III. ATURAN KOMBINASI $m_{5}$ UNTUK CONTOH PERHITUNGAN TEORITIS

\begin{tabular}{|l|l|l|}
\hline \multirow{2}{*}{$m_{3}$} & \multicolumn{2}{|c|}{$m_{4}$} \\
\cline { 2 - 3 } & \multicolumn{1}{|c|}{$m_{4}\{\mathrm{P} 1, \mathrm{P} 2\}=0.8$} & $m_{4}\{\theta\}=0.2$ \\
\hline$m_{3}\{\mathrm{P} 1\}=0.8$ & $\{\mathrm{P} 1\}=0.8 \times 0.8=0.64$ & $\{\mathrm{P} 1\}=0.8 \times 0.2=0.16$ \\
\hline$m_{3}\{\mathrm{P} 1, \mathrm{P} 2\}=0.2$ & $\{\mathrm{P} 1, \mathrm{P} 2\}=0.2 \times 0.8=$ & $\{\mathrm{P} 1, \mathrm{P} 2\}=0.2 \times 0.2$ \\
\hline$m_{3}\{\mathrm{P} 1, \mathrm{P} 6, \mathrm{P} 8\}=0$ & 0.16 & $=0.04$ \\
\hline$m_{3}\{\mathrm{\theta}\}=0$ & $\{\mathrm{P} 1\}=0 \times 0.8=0$ & $\{\mathrm{P} 1, \mathrm{P} 6, \mathrm{P} 8\}=0 \times 0.2=0$ \\
\hline
\end{tabular}


Sehingga dapat dihitung nilai densitas baru $m_{5}$ :

$$
\begin{aligned}
& m_{5}\{\mathrm{P} 1\}=\frac{0.64+0+0.16}{1-0}=0.8 \\
& m_{5}\{\mathrm{P} 1, \mathrm{P} 2\}=\frac{0.16+0+0.04}{1-0}=0.2 \\
& m_{5}\{\mathrm{P} 1, \mathrm{P} 6, \mathrm{P} 8\}=0 \\
& m_{5}\{\theta\}=0
\end{aligned}
$$

d. Gejala 4: Tidak ada tulang yang menonjol atau tidak ada luka terbuka pada kulit

$$
\begin{aligned}
& m_{6}\{\mathrm{P} 1\}=0.8 \\
& m_{6}\{\theta\}=1-0.8=0.2
\end{aligned}
$$

TABEL IV. ATURAN KOMBINASI $m_{7}$ UNTUK CONTOH PERHITUNGAN TEORITIS

\begin{tabular}{|l|l|l|}
\hline \multirow{2}{*}{$m_{5}$} & \multicolumn{2}{|c|}{$m_{6}$} \\
\cline { 2 - 3 } & \multicolumn{1}{|c|}{$m_{6}\{\mathrm{P} 1\}=0.8$} & $m_{6}\{\Theta\}=0.2$ \\
\hline$m_{5}\{\mathrm{P} 1\}=0.8$ & $\{\mathrm{P} 1\}=0.8 \times 0.8=0.64$ & $\{\mathrm{P} 1\}=0.8 \times 0.2=0.16$ \\
\hline$m_{5}\{\mathrm{P} 1, \mathrm{P} 2\}=0.2$ & $\{\mathrm{P} 1\}=0.2 \times 0.8=0.16$ & $\begin{array}{l}\{\mathrm{P} 1, \mathrm{P} 2\}=0.2 \times 0.2 \\
=0.04\end{array}$ \\
\hline$m_{5}\{\mathrm{P} 1, \mathrm{P} 6, \mathrm{P} 8\}=0$ & $\{\mathrm{P} 1\}=0 \times 0.8=0$ & $\begin{array}{l}\{\mathrm{P} 1, \mathrm{P} 6, \mathrm{P} 8\}=0 \times 0.2 \\
=0\end{array}$ \\
\hline$m_{5}\{\Theta\}=0$ & $\{\mathrm{P} 1\}=0 \times 0.8=0$ & $\{\Theta\}=0 \times 0.2=0$ \\
\hline
\end{tabular}

Sehingga dapat dihitung nilai densitas baru $m_{7}$ :

$$
\begin{aligned}
& m_{7}\{\mathrm{P} 1\}=\frac{0.64+0.16+0+0+0.16}{1-0}=0.96 \\
& m_{7}\{\mathrm{P} 1, \mathrm{P} 2\}=\frac{0.04}{1-0}=0.04 \\
& m_{5}\{\mathrm{P} 1, \mathrm{P} 6, \mathrm{P} 8\}=0 \\
& m_{7}\{\mathrm{\theta}\}=0
\end{aligned}
$$

Berdasarkan perhitungan dengan metode Dempster Shafer, diperoleh nilai densitas tertinggi 0.96 atau dengan persentase sebesar 96\% yaitu P1 yang merupakan kode penyakit Patah tulang tertutup.

Gambar 6 merupakan tampilan hasil diagnosa sistem jika dimasukkan 4 gejala seperti pada Tabel I. Hasil yang ditampilkan adalah pasien mengidap penyakit Patah Tulang Tertutup dengan persentase kemungkinan sebesar $96 \%$ yang diperoleh dari proses perhitungan dengan rumus metode dempster pada system yang membuktikan bahwa hasil pengujian dengan perhitungan teoritis sesuai dengan hasil diagnosa sistem.

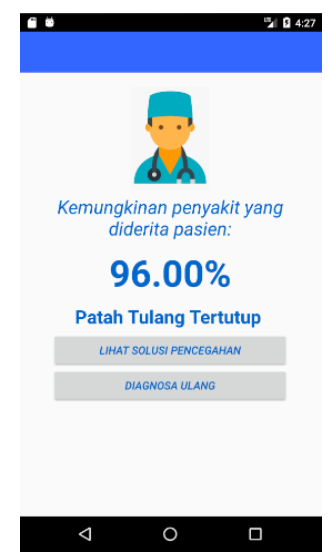

Gambar 6. Hasil pengujian dengan perhitungan manual pada system

\section{A.3. Pengujian Akurasi Sistem}

Pengujian akurasi sistem dilakukan oleh 3 orang pakar dari dokter spesialis ortopedi. Tujuan dilakukannya pengujian ini yaitu untuk mengetahui kesesuaian antara hasil diagnosa pakar dan hasil diagnosa sistem berdasakan 30 contoh kasus yang diujikan kepada pakar.

Pada pengujian dengan contoh kasus, ditampilkan beberapa gejala yang dirasakan oleh pasien beserta daftar kemungkinan penyakit yang diderita berdasarkan gejalagejala tersebut. Lalu dokter spesialis ortopedi selaku pakar diminta untuk mendiagnosis kasus tersebut. Gejala dan penyakit yang ditampilkan pada form pengujian sesuai dengan data yang telah tersimpan pada basis pengetahuan sistem pakar kelainan ortopedi yang dimana data tersebut diperoleh dari pakar. Selanjutnya kasus yang diujikan pada pakar akan diujikan juga ke dalam sistem. Gejala-gejala yang terdapat pada kasus di masukkan ke dalam sistem, kemudian mesin inferensi sistem yakni forward chaining sebagai salah satu komponen dari sistem mulai bekerja dengan melakukan penelusuran informasi berupa mencari tahu kemungkinan penyakit yang terjadi beserta bobotnya berdasarkan gejala yang dimasukkan. Setelah informasi kemungkinan penyakit dan bobot masing-masing gejala pada setiap penyakit diperoleh, selanjutnya dilakukan proses perhitungan dengan menggunakan metode dempster shafer (sesuai dengan tahapan pada pengujian dengan perhitungan teoritis) untuk memperoleh kesimpulan berupa hasil diagnosa penyakit beserta persentase kemungkinannya yang selanjutnya akan ditampilkan pada sistem.

Pengujian akurasi sistem dilakukan dengan dua skenario yaitu perhitungan akurasi berdasarkan nilai belief (bobot) masing-masing pakar dan berdasarkan nilai belief (bobot) rata-rata ketiga pakar yakni pakar 1, pakar 2 dan pakar 3 (P1, P2, P3). Hasil pengujian akurasi dari dokter selaku pakar dan hasil pengujian dari sistem berdasarkan proses penalaran dengan metode forward chaining dan perhitungan dengan metode Dempster Shafer disajikan dalam bentuk tabel pada Tabel V, Tabel VI, Tabel VII dan Tabel VIII

\section{A.3.1 Pengujian Akurasi berdasarkan bobot rata-rata}

Hasil pengujian akurasi berdasarkan bobot rata-rata ketiga pakar dapat dilihat pada Tabel V. Berdasarkan hasil pengujian akurasi pada Tabel $\mathrm{V}$ diperoleh nilai akurasi ratarata berdasarkan bobot rata-rata pakar sebesar $81.11 \%$. Adanya kasus yang tidak valid antara hasil diagnosa pakar dengan hasil diagnosa pada sistem dipengaruhi oleh besarnya bobot yang diberikan oleh masing-masing pakar serta pengalaman pakar dalam menangani pasien.

\section{A.3.2 Pengujian Akurasi berdasarkan bobot masing- masing pakar}

Hasil pengujian akurasi berdasarkan bobot masingmasing pakar dapat dilihat pada Tabel VII. 
TABEL V. Hasil Pengujian dengan Bobot Rata-Rata

\begin{tabular}{|c|c|c|c|}
\hline $\begin{array}{c}\text { Hasil diagnosa } \\
\text { sistem }\end{array}$ & $\begin{array}{c}\text { Hasil diagnosa } \\
\text { P1 }\end{array}$ & $\begin{array}{c}\text { Hasil diagnosa } \\
\text { P2 }\end{array}$ & $\begin{array}{c}\text { Hasil diagnosa } \\
\text { P3 }\end{array}$ \\
\hline $\begin{array}{l}\text { Patah tulang } \\
\text { tertutup (98.93\%) }\end{array}$ & $\begin{array}{l}\text { Osteomielitis } \\
\text { Kronis }\end{array}$ & $\begin{array}{l}\text { Patah Tulang } \\
\text { Tertutup, } \\
\text { Osteomielitis } \\
\text { Akut }\end{array}$ & $\begin{array}{l}\text { Osteomielitis } \\
\text { Akut }\end{array}$ \\
\hline $\begin{array}{l}\text { Osteomielitis akut } \\
(99.77 \%)\end{array}$ & $\begin{array}{l}\text { Osteomielitis } \\
\text { Akut }\end{array}$ & $\begin{array}{l}\text { Osteomielitis } \\
\text { Akut }\end{array}$ & $\begin{array}{l}\text { Osteomielitis } \\
\text { Akut }\end{array}$ \\
\hline $\begin{array}{l}\text { Rheumatoid } \\
\text { Arthritis } \\
(82,24 \%) \\
\end{array}$ & Osteoartritis & $\begin{array}{l}\text { Osteoarthritis, } \\
\text { Gout Arthritis }\end{array}$ & $\begin{array}{l}\text { Rheumatoid } \\
\text { Arthritis }\end{array}$ \\
\hline $\begin{array}{l}\text { Osteoporosis } \\
(100 \%)\end{array}$ & Osteoporosis & $\begin{array}{l}\text { Patah Tulang } \\
\text { Tertutup, } \\
\text { Oteoporosis }\end{array}$ & Osteoporosis \\
\hline $\begin{array}{l}\text { Spondilitis TB } \\
(78.72 \%)\end{array}$ & Spondilitis TB & $\begin{array}{l}\text { Spondilitis TB, } \\
\text { Osteomielitis } \\
\text { Kronis }\end{array}$ & Spondilitis TB \\
\hline $\begin{array}{l}\text { Ricketsia } \\
(99.97 \%) \\
\end{array}$ & Ricketsia & Ricketsia & Ricketsia \\
\hline $\begin{array}{l}\text { Gout Arthritis } \\
(99.11 \%)\end{array}$ & Gout Arthritis & Gout Arthritis & Gout Arthritis \\
\hline $\begin{array}{l}\text { Scoliosis } \\
(99.54 \%)\end{array}$ & Scoliosis & $\begin{array}{l}\text { Osteomielitis } \\
\text { Akut, Scoliosis }\end{array}$ & Scoliosis \\
\hline $\begin{array}{l}\text { Rheumatoid } \\
\text { Arthritis } \\
(95.93 \%) \\
\end{array}$ & $\begin{array}{l}\text { Rheumatoid } \\
\text { Arthritis }\end{array}$ & $\begin{array}{l}\text { Osteoarthritis, } \\
\text { Rheumatoid } \\
\text { Arthritis }\end{array}$ & Osteoarthritis \\
\hline $\begin{array}{l}\text { Ricketsia } \\
(99.04 \%) \\
\end{array}$ & Ricketsia & Ricketsia & Ricketsia \\
\hline $\begin{array}{l}\text { Gout Arthritis } \\
(89.32 \%)\end{array}$ & Gout Arthritis & $\begin{array}{l}\text { Gout Arthritis, } \\
\text { Rheumatoid } \\
\text { Arthritis }\end{array}$ & Gout Arthritis \\
\hline $\begin{array}{l}\text { Patah Tulang } \\
\text { Terbuka }(100 \%)\end{array}$ & $\begin{array}{l}\text { Osteomielitis } \\
\text { Kronis }\end{array}$ & $\begin{array}{l}\text { Patah Tulang } \\
\text { Terbuka }\end{array}$ & $\begin{array}{l}\text { Patah Tulang } \\
\text { Terbuka }\end{array}$ \\
\hline $\begin{array}{l}\begin{array}{l}\text { Osteoarthritis } \\
(89.61 \%)\end{array} \\
\end{array}$ & Ricketsia & Ricketsia & Ricketsia \\
\hline $\begin{array}{l}\text { Osteochondroma } \\
(51.71 \%)\end{array}$ & Spondilitis TB & $\begin{array}{l}\text { Ricketsia, } \\
\text { Scoliosis } \\
\end{array}$ & Spondilitis TB \\
\hline $\begin{array}{l}\text { Osteosarcoma } \\
(99.62 \%)\end{array}$ & Osteosarcoma & $\begin{array}{l}\text { Rheumatoid } \\
\text { Arthritis, } \\
\text { Osteosarcoma }\end{array}$ & Osteosarcoma \\
\hline $\begin{array}{l}\text { Patah Tulang } \\
\text { Terbuka (100\%) }\end{array}$ & $\begin{array}{l}\text { Patah Tulang } \\
\text { Terbuka }\end{array}$ & $\begin{array}{l}\text { Patah Tulang } \\
\text { Terbuka }\end{array}$ & $\begin{array}{l}\text { Patah Tulang } \\
\text { Terbuka }\end{array}$ \\
\hline $\begin{array}{l}\text { Scoliosis } \\
(99.91 \%)\end{array}$ & Scoliosis & $\begin{array}{l}\text { Spondilitis TB, } \\
\text { Scoliosis }\end{array}$ & Scoliosis \\
\hline $\begin{array}{l}\text { Spondilitis TB } \\
(95.07 \%)\end{array}$ & Spondilitis TB & Spondilitis TB & Spondilitis TB \\
\hline $\begin{array}{l}\text { Scoliosis } \\
(99.55 \%)\end{array}$ & Spondilitis TB & $\begin{array}{l}\text { Spondilitis TB, } \\
\text { Scoliosis }\end{array}$ & Scoliosis \\
\hline $\begin{array}{l}\text { Spondilitis TB } \\
(90.1 \%)\end{array}$ & Spondilitis TB & Spondilitis TB & Scoliosis \\
\hline $\begin{array}{l}\text { Osteoporosis } \\
(100 \%)\end{array}$ & Osteoporosis & $\begin{array}{l}\text { Patah Tulang } \\
\text { Tertutup, } \\
\text { Osteoarthritis, } \\
\text { Osteoporosis }\end{array}$ & Osteoporosis \\
\hline $\begin{array}{l}\text { Osteomielitis } \\
\text { Kronis }(97.55 \%)\end{array}$ & $\begin{array}{l}\text { Osteomielitis } \\
\text { Kronis }\end{array}$ & $\begin{array}{l}\text { Osteomielitis } \\
\text { Kronis, } \\
\text { Osteosarcoma }\end{array}$ & $\begin{array}{l}\text { Osteomielitis } \\
\text { Kronis }\end{array}$ \\
\hline $\begin{array}{l}\text { Osteosarcoma } \\
(98.96 \%)\end{array}$ & Osteosarcoma & $\begin{array}{l}\text { Osteoarthritis, } \\
\text { Osteosarcoma }\end{array}$ & Osteosarcoma \\
\hline $\begin{array}{l}\text { Osteomielitis } \\
\text { Kronis }(53.62 \%)\end{array}$ & $\begin{array}{l}\text { Osteomielitis } \\
\text { Kronis }\end{array}$ & $\begin{array}{l}\text { Osteomielitis } \\
\text { Kronis }\end{array}$ & $\begin{array}{l}\text { Osteomielitis } \\
\text { Kronis }\end{array}$ \\
\hline $\begin{array}{l}\text { Osteochondroma } \\
(99.49 \%)\end{array}$ & Osteochondroma & Scoliosis & Osteochondroma \\
\hline $\begin{array}{l}\text { Osteomielitis } \\
\text { Akut }(99.91 \%)\end{array}$ & $\begin{array}{l}\text { Osteomielitis } \\
\text { Akut }\end{array}$ & $\begin{array}{l}\text { Osteomielitis } \\
\text { Kronis }\end{array}$ & $\begin{array}{l}\text { Osteomielitis } \\
\text { Akut }\end{array}$ \\
\hline $\begin{array}{l}\text { Ricketsia } \\
(97.49 \%) \\
\end{array}$ & Ricketsia & Ricketsia & Ricketsia \\
\hline $\begin{array}{l}\text { Osteoporosis } \\
(100 \%)\end{array}$ & Osteoporosis & $\begin{array}{l}\text { Osteoarthritis, } \\
\text { Osteoporosis }\end{array}$ & Osteoporosis \\
\hline $\begin{array}{l}\text { Osteoartritis } \\
(99.45 \%)\end{array}$ & Osteoartritis & $\begin{array}{l}\text { Osteoarthritis, } \\
\text { Gout Arthritis, } \\
\text { Rheumatoid } \\
\text { Arthritis } \\
\end{array}$ & Osteoartritis \\
\hline $\begin{array}{l}\text { Gout Arthritis } \\
(99.39 \%)\end{array}$ & Gout Arthritis & $\begin{array}{l}\text { Osteoarthritis, } \\
\text { Gout Arthritis, } \\
\text { Rheumatoid } \\
\text { Arthritis }\end{array}$ & $\begin{array}{l}\text { Rheumatoid } \\
\text { Arthritis }\end{array}$ \\
\hline
\end{tabular}

TABEL VI. Hasil Pengujian DENGan Bobot Pakar 1

\begin{tabular}{|c|c|c|}
\hline Hasil diagnosa pakar 1 & $\begin{array}{c}\text { Hasil diagnosa sistem } \\
\text { berdasarkan bobot pakar 1 }\end{array}$ & Keterangan \\
\hline Osteomielitis Kronis & Patah tulang tertutup (100\%) & Tidak Valid \\
\hline Osteomielitis Akut & Osteomielitis Akut (100\%) & Valid \\
\hline Osteoartritis & $\begin{array}{l}\text { Rheumatoid Arthritis } \\
(80,57 \%)\end{array}$ & Tidak Valid \\
\hline Osteoporosis & Osteoporosis $(100 \%)$ & Valid \\
\hline Spondilitis TB & $\begin{array}{l}\text { Patah tulang tertutup, Patah } \\
\text { tulang terbuka }(100 \%)\end{array}$ & Tidak Valid \\
\hline Ricketsia & Ricketsia $(100 \%)$ & Valid \\
\hline Gout Arthritis & Gout Arthritis (100\%) & Valid \\
\hline Scoliosis & Scoliosis (100\%) & Valid \\
\hline Rheumatoid Arthritis & Rheumatoid Arthritis (100\%) & Valid \\
\hline Ricketsia & Ricketsia $(100 \%)$ & Valid \\
\hline Gout Arthritis & Gout Arthritis (100\%) & Valid \\
\hline Osteomielitis Kronis & Patah tulang terbuka(100\%) & Tidak Valid \\
\hline Ricketsia & Ricketsia $(100 \%)$ & Valid \\
\hline Spondilitis TB & Osteochondroma (80\%) & Tidak Valid \\
\hline Osteosarcoma & Osteosarcoma $(100 \%)$ & Valid \\
\hline Patah Tulang Terbuka & Patah tulang terbuka (100\%) & Valid \\
\hline Scoliosis & Scoliosis $(100 \%)$ & Valid \\
\hline Spondilitis TB & Spondilitis TB $(96,20 \%)$ & Valid \\
\hline Spondilitis TB & Scoliosis $(100 \%)$ & Tidak Valid \\
\hline Spondilitis TB & Spondilitis TB $(100 \%)$ & Valid \\
\hline Osteoporosis & Osteoporosis $(100 \%)$ & Valid \\
\hline Osteomielitis Kronis & Osteomielitis Kronis (100\%) & Valid \\
\hline Osteosarcoma & Osteosarcoma (99\%) & Valid \\
\hline Osteomielitis Kronis & Osteomielitis Kronis ( $80 \%)$ & Valid \\
\hline Osteochondroma & Osteochondroma $(100 \%)$ & Valid \\
\hline Osteomielitis Akut & Osteomielitis Akut (100\%) & Valid \\
\hline Ricketsia & Ricketsia $(100 \%)$ & Valid \\
\hline Osteoporosis & Osteoporosis (100\%) & Valid \\
\hline Osteoartritis & Osteoartritis (100\%) & Valid \\
\hline Gout Arthritis & Gout Arthritis (100\%) & Valid \\
\hline
\end{tabular}

Berdasarkan hasil pengujian akurasi pada Tabel VI terdapat 24 kasus yang sesuai dan 6 kasus tidak sesuai antara hasil diagnosa sistem berdasarkan bobot pakar 1 dengan hasil diagnosa pakar. Sehingga diperoleh akurasi sebesar $\frac{24}{30} x 100 \%=80 \%$. Adanya kasus yang tidak valid antara hasil diagnosa pakar dengan hasil diagnosa pada system dipengaruhi oleh besarnya bobot yang diberikan oleh masing-masing pakar serta pengalaman pakar dalam menangani pasien.

Berdasarkan hasil pengujian akurasi pada Tabel VII terdapat 25 kasus yang sesuai dan 5 kasus tidak sesuai antara hasil diagnosa sistem berdasarkan bobot pakar 2 dengan hasil diagnosa pakar. Sehingga diperoleh akurasi sebesar $\frac{25}{30} x 100 \%=83.33 \%$. Adanya kasus yang tidak valid antara hasil diagnosa pakar dengan hasil diagnosa pada sistem dipengaruhi oleh besarnya bobot yang diberikan oleh masing-masing pakar serta pengalaman pakar dalam menangani pasien. 
TABEL VII. Hasil PENGUJIAN DENGAN Bobot PAKAR 2

\begin{tabular}{|c|c|c|}
\hline Hasil diagnosa pakar 2 & $\begin{array}{c}\text { Hasil diagnosa sistem } \\
\text { berdasarkan bobot pakar } 2\end{array}$ & Keterangan \\
\hline $\begin{array}{l}\text { Patah Tulang Tertutup, } \\
\text { Osteomielitis Akut }\end{array}$ & Patah Tulang Tertutup (100\%) & Valid \\
\hline Osteomielitis Akut & Osteomielitis Akut (100\%) & Valid \\
\hline $\begin{array}{l}\text { Osteoarthritis, Gout } \\
\text { Arthritis }\end{array}$ & $\begin{array}{l}\text { Rheumatoid Arthritis } \\
(98,01 \%)\end{array}$ & Tidak Valid \\
\hline $\begin{array}{l}\text { Patah Tulang Tertutup, } \\
\text { Oteoporosis }\end{array}$ & Osteoporosis (100\%) & Valid \\
\hline $\begin{array}{l}\text { Spondilitis } \mathrm{TB}, \\
\text { Osteomielitis } \text { Kronis }\end{array}$ & Spondilitis TB (97.09\%) & Valid \\
\hline Ricketsia & Ricketsia $(99.98 \%)$ & Valid \\
\hline Gout Arthritis & Gout Arthritis (100\%) & Valid \\
\hline $\begin{array}{l}\text { Osteomielitis Akut, } \\
\text { Scoliosis }\end{array}$ & Scoliosis $(99.76 \%)$ & Valid \\
\hline $\begin{array}{l}\text { Osteoarthritis, } \\
\text { Rheumatoid Arthritis }\end{array}$ & Rheumatoid Arthritis (100\%) & Valid \\
\hline Ricketsia & Ricketsia $(99.57 \%)$ & Valid \\
\hline $\begin{array}{l}\text { Gout Arthritis, } \\
\text { Rheumatoid Arthritis }\end{array}$ & Gout Arthritis (100\%) & Valid \\
\hline Patah Tulang Terbuka & Patah Tulang Terbuka (100\%) & Valid \\
\hline Ricketsia & Osteoarthritis $(97.90 \%)$ & Tidak Valid \\
\hline Ricketsia, Scoliosis & Osteochondroma $(76.47 \%)$ & Tidak Valid \\
\hline $\begin{array}{l}\text { Rheumatoid Arthritis, } \\
\text { Osteosarcoma }\end{array}$ & Osteosarcoma $(99.90 \%)$ & Valid \\
\hline Patah Tulang Terbuka & Patah Tulang Terbuka (100\%) & Valid \\
\hline Spondilitis TB, Scoliosis & Scoliosis $(100 \%)$ & Valid \\
\hline Spondilitis TB & Spondilitis TB (99.17\%) & Valid \\
\hline Spondilitis TB, Scoliosis & Scoliosis $(99.64 \%)$ & Valid \\
\hline Spondilitis $\mathrm{TB}$ & Spondilitis TB $(87.49 \%)$ & Valid \\
\hline $\begin{array}{l}\text { Patah Tulang Tertutup, } \\
\text { Osteoarthritis, } \\
\text { Osteoporosis }\end{array}$ & Osteoporosis (100\%) & Valid \\
\hline $\begin{array}{l}\text { Osteomielitis Kronis, } \\
\text { Osteosarcoma }\end{array}$ & Osteomielitis Kronis (99.47\%) & Valid \\
\hline $\begin{array}{l}\text { Osteoarthritis, } \\
\text { Osteosarcoma }\end{array}$ & Osteosarcoma $(99.96 \%)$ & Valid \\
\hline Osteomielitis Kronis & Osteomielitis Kronis (63.64\%) & Valid \\
\hline Scoliosis & Osteochondroma $(99.45 \%)$ & Tidak Valid \\
\hline Osteomielitis Kronis & Osteomielitis Akut (100\%) & Tidak Valid \\
\hline Ricketsia & Ricketsia $(99.69 \%)$ & Valid \\
\hline $\begin{array}{l}\text { Osteoarthritis, } \\
\text { Osteoporosis }\end{array}$ & Osteoporosis (100\%) & Valid \\
\hline $\begin{array}{l}\text { Osteoarthritis, Gout } \\
\text { Arthritis, Rheumatoid } \\
\text { Arthritis }\end{array}$ & Osteoarthritis (100\%) & Valid \\
\hline $\begin{array}{l}\text { Osteoarthritis, Gout } \\
\text { Arthritis, Rheumatoid } \\
\text { Arthritis }\end{array}$ & Gout Arthritis (100\%) & Valid \\
\hline
\end{tabular}

Berdasarkan hasil pengujian akurasi pada Tabel VIII terdapat 22 kasus yang sesuai dan 8 kasus tidak sesuai antara hasil diagnosa sistem berdasarkan bobot pakar 3 dengan hasil diagnosa pakar 3. Sehingga diperoleh akurasi sebesar $\frac{22}{30} x 100 \%=73.33 \%$. Adanya kasus yang tidak valid antara hasil diagnosa pakar dengan hasil diagnosa pada sistem dipengaruhi oleh besarnya bobot yang diberikan oleh masing-masing pakar serta pengalaman pakar dalam menangani pasien.

Berdasarkan dua skenario pengujian akurasi yang dilakukan, diperoleh nilai akurasi berdasarkan bobot ratarata pakar sebesar $81.11 \%$. Sedangkan untuk pengujian akurasi berdasarkan bobot masig-masing pakar secara berurutan sebesar $80 \%, 83.33 \%$ dan $73.33 \%$.

Berdasarkan hasil pengujian akurasi dengan 2 skenario tersebut dapat dikatakan bahwa penerapan metode forward chaining sebagai mesin inferensi dan Dempster Shafer untuk mengambil kesimpulan berdasarkan pengetahun 3 orang pakar pada sistem telah berhasil diimplementasikan dan memberikan hasil diagnosa yang tepat berdasrkan 30 contoh kasus.
TABEL VIII. Hasil PENGUJIAN DENGan Bobot PAKAR 3

\begin{tabular}{|c|c|c|}
\hline Hasil diagnosa pakar 3 & $\begin{array}{c}\text { Hasil diagnosa sistem } \\
\text { berdasarkan bobot pakar } 3\end{array}$ & Keterangan \\
\hline Osteomielitis Akut & Patah Tulang Tertutup (96\%) & Tidak Valid \\
\hline Osteomielitis Akut & Osteomielitis Akut (99.01\%) & Valid \\
\hline Rheumatoid Arthritis & Rheumatoid Arthritis (44.94\%) & Valid \\
\hline Osteoporosis & Osteoporosis (100\%) & Valid \\
\hline Spondilitis TB & $\begin{array}{l}\text { Patah Tulang Tertutup (100\%) } \\
\text { Patah Tulang Terbuka }(100 \%)\end{array}$ & Tidak Valid \\
\hline Ricketsia & Ricketsia $(99.88 \%)$ & Valid \\
\hline Gout Arthritis & Gout Arthritis (94.80\%) & Valid \\
\hline Scoliosis & Scoliosis $(97.05 \%)$ & Valid \\
\hline Osteoarthritis & Rheumatoid Arthritis (86.61\%) & Tidak Valid \\
\hline Ricketsia & Ricketsia $(97.78 \%)$ & Valid \\
\hline Gout Arthritis & Gout Arthritis (64\%) & Valid \\
\hline Patah Tulang Terbuka & Patah Tulang Terbuka (100\%) & Valid \\
\hline Ricketsia & Osteoarthritis $(84.1 \%)$ & Tidak Valid \\
\hline Spondilitis TB & Scoliosis $(52.93 \%)$ & Tidak Valid \\
\hline Osteosarcoma & Osteosarcoma $(97.2 \%)$ & Valid \\
\hline Patah Tulang Terbuka & Patah Tulang Terbuka (100\%) & Valid \\
\hline Scoliosis & Scoliosis $(99.40 \%)$ & Valid \\
\hline Spondilitis TB & Spondilitis TB (84\%) & Valid \\
\hline Scoliosis & Scoliosis $(99.56 \%)$ & Valid \\
\hline Scoliosis & Spondilitis TB $(53.12 \%)$ & Tidak Valid \\
\hline Osteoporosis & Osteoporosis (100\%) & Valid \\
\hline Osteomielitis Kronis & Osteomielitis Kronis (80.8\%) & Valid \\
\hline Osteosarcoma & Osteosarcoma $(96.64 \%)$ & Valid \\
\hline Osteomielitis Kronis & $\begin{array}{l}\text { Osteomielitis Kronis }(65.73 \%) \\
\text { Osteomielitis Akut }(65.73)\end{array}$ & Tidak Valid \\
\hline Osteochondroma & Osteochondroma $(97.84 \%)$ & Valid \\
\hline Osteomielitis Akut & Osteomielitis Akut (99.02\%) & Valid \\
\hline Ricketsia & Ricketsia $(98.02 \%)$ & Valid \\
\hline Osteoporosis & Osteoporosis (100\%) & Valid \\
\hline Osteoartritis & Osteoartritis $(96.79 \%)$ & Valid \\
\hline Rheumatoid Arthritis & Gout Arthritis (95.5\%) & Tidak Valid \\
\hline
\end{tabular}

\section{A.4. Pengujian MOS (Mean Opinion Score)}

Pengujian MOS dilakukan dengan memberikan beberapa pertanyaan kepada responden dalam bentuk kuesioner. Responden pada penelitian ini berjumlah 30 orang yang terdiri dari 10 orang mahasiswa TI, 5 orang mahasiswa kedokteran, 5 orang tenaga medis dan 10 orang masyarakat umum. Pengujian MOS dilakukan untuk mengetahui tanggapan pengguna (responden) terhadap sistem berdasarkan disiplin ilmu masng-masing dan sebagai penguna Android kemudian hasil penilaian dihitung dengan parameter MOS untuk mendapatkan kesimpulan hasil pengujian.

Hasil pengujian parameter MOS yang diberikan oleh 10 orang responden mahasiswa PSTI dapat dilihat pada Tabel IX.

TABEL IX. PENGUJIAN MOS RESPONDEN MAHASISWA TI

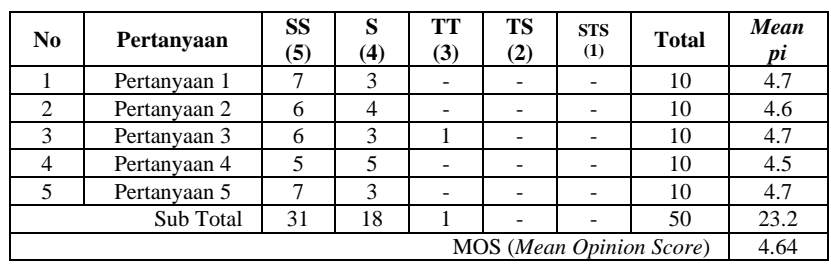

\section{Keterangan:}

Pertanyaan 1: $\quad$ Tampilan sistem pakar diagnosa kelainan tulang ini menarik dan mudah digunakan (user friendly)

Pertanyaan 2: Penggunaan warna tampilan dan jenis huruf pada sistem pakar ini sudah sesuai 
Pertanyaan 3:

Menu yang ditampilkan pada sistem sudah cukup dan sesuai (tidak diperlukan menu pengurangan atau penambahan lagi)

Pertanyaan 4: Informasi yang ditampilkan sesuai dengan tujuan pembangunan sistem

Pertanyaan 5: $\quad$ Sistem pakar diagnosa kelainan tulang ini layak digunakan

Berdasarkan Tabel IX dapat dilihat bahwa diperoleh hasil perhitungan nilai akhir MOS sebesar 4.64. Berdasarkan nilai tersebut dapat disimpulkan tujuan pengujian MOS oleh mahasiswa PSTI untuk mengetahui kelayakan sistem dari sisi teknis (tampilan, user friendly, fungsionalitas) sudah tercapai karena berdasarkan tabel skala opinion dan bobot diketahui bahwa sistem yang berada pada rentang nilai MOS 4 sampai dengan 5 dikelompokkan ke dalam kategori sistem good (baik).

Hasil pengujian parameter MOS yang diberikan oleh 5 orang responden mahasiswa kedokteran dapat dilihat pada Tabel X.

TABEL X. PEnguJIAN MOS RESPONDEN MAHASISWA KedOKTERAN

\begin{tabular}{|c|c|c|c|c|c|c|c|c|}
\hline No & Pertanyaan & $\begin{array}{l}\text { SS } \\
(5)\end{array}$ & $\begin{array}{c}\text { S } \\
(4)\end{array}$ & $\begin{array}{l}\text { TT } \\
(3)\end{array}$ & $\begin{array}{l}\text { TS } \\
(2)\end{array}$ & $\begin{array}{c}\text { STS } \\
(1)\end{array}$ & Total & Mean pi \\
\hline 1 & Pertanyaan 1 & 3 & 2 & - & - & - & 5 & 4.6 \\
\hline 2 & Pertanyaan 2 & 3 & 2 & - & - & - & 5 & 4.6 \\
\hline 3 & Pertanyaan 3 & 3 & 2 & - & - & - & 5 & 4.6 \\
\hline 4 & Pertanyaan 4 & 3 & 2 & - & - & - & 5 & 4.6 \\
\hline 5 & Pertanyaan 5 & 3 & 2 & - & - & - & 5 & 4.6 \\
\hline \multirow{2}{*}{\multicolumn{8}{|c|}{\begin{tabular}{c|c|c|c}
- & - & - & 25 \\
\multicolumn{3}{l|}{ MOS (Mean Opinion Score) }
\end{tabular}}} & 23 \\
\hline & & & & & & & & 4.6 \\
\hline
\end{tabular}

\section{Keterangan:}

Pertanyaan 1: Tampilan sistem pakar diagnosa kelainan tulang ini menarik dan mudah digunakan (user friendly)

Pertanyaan 2: $\quad$ Informasi penyakit dan gejala yang ditampilkan sudah sesuai dan tidak bertentangan dengan yang dipelajari di perkuliahan

Pertanyaan 3: $\quad$ Pemilihan gambar pendukung sesuai dengan informasi yang ditampilkan

Pertanyaan 4: Sistem pakar ini dapat memberikan informasi saran pencegahan kelainan tulang

Pertanyaan 5: Sitem pakar ini dapat membantu melakukan diagnosa kelainan tulang menjadi lebih mudah dan layak digunakan

Berdasarkan Tabel $\mathrm{X}$ dapat dilihat bahwa diperoleh hasil perhitungan nilai akhir MOS sebesar 4.6. Berdasarkan nilai tersebut dapat disimpulkan tujuan pengujian MOS oleh mahasiswa kedokteran untuk mengetahui kelayakan sistem dari sisi kesesuaian informasi yang ditampilkan dengan apa yang dipelajari selama perkuliahan di Fakultas Kedokteran dan kemudahan dalam pengunaan aplikasi sudah tercapai karena berdasarkan tabel skala opinion dan bobot diketahui bahwa sistem yang berada pada rentang nilai MOS 4 sampai dengan 5 dikelompokkan ke dalam kategori sistem good (baik).

Hasil pengujian parameter MOS yang diberikan oleh 5 orang responden tenaga medis dapat dilihat pada Tabel XI.

TABEL XI. PEngujian MOS RESPONDEN TenAga Medis

\begin{tabular}{|c|c|c|c|c|c|c|c|c|}
\hline No & Pertanyaan & $\begin{array}{l}\text { SS } \\
(5)\end{array}$ & $\begin{array}{c}\text { S } \\
(4)\end{array}$ & $\begin{array}{l}\text { TT } \\
(3)\end{array}$ & $\begin{array}{l}\text { TS } \\
(2)\end{array}$ & $\begin{array}{c}\text { STS } \\
(1)\end{array}$ & Total & $\begin{array}{c}\text { Mean } \\
\text { pi }\end{array}$ \\
\hline 1 & Pertanyaan 1 & - & 5 & - & - & - & 5 & 4 \\
\hline 2 & Pertanyaan 2 & - & 5 & - & - & - & 5 & 4 \\
\hline 3 & Pertanyaan 3 & - & 5 & - & - & - & 5 & 4 \\
\hline 4 & Pertanyaan 4 & 1 & 4 & - & - & - & 5 & 4.2 \\
\hline 5 & Pertanyaan 5 & - & 5 & - & - & - & 5 & 2 \\
\hline \multirow{2}{*}{\multicolumn{8}{|c|}{\begin{tabular}{c|c|c|c}
- & - & - & 25 \\
\multicolumn{1}{l}{ MOS (Mean Opinion Score) }
\end{tabular}}} & 20.2 \\
\hline & & & & & & & & 4.04 \\
\hline
\end{tabular}

\section{Keterangan:}

Pertanyaan 1: Tampilan sistem pakar diagnosa kelainan tulang ini menarik dan mudah digunakan (user friendly)

Pertanyaan 2: $\quad$ Informasi gejala dan penyakit yang ditampilkan sudah sesuai/relevan dengan yang dirasakan/dikeluhkan masyarakat

Pertanyaan 3: Informasi saran pencegahan yang ditampilkan sudah sesuai dan layak untuk diterapkan masyarakat

Pertanyaan 4: Kesesuaian antara pemilihan gejala dengan hasil diagnosa yang ditampilkan sistem

Pertanyaan 5: $\quad$ Sistem pakar diagnosa kelainan tulang ini layak digunakan berdasarkan keakuratan informasi yang disajikan

Berdasarkan Tabel XI dapat dilihat bahwa diperoleh hasil perhitungan nilai akhir MOS sebesar 4.04. Berdasarkan nilai tersebut dapat disimpulkan tujuan pengujian MOS oleh tenaga medis untuk mengetahui kelayakan sistem dari sisi kesesuaian informasi gejala dan hasil diagnosa yang ditampilkan berdasarkan pengalaman menangani pasien dan kemudahan dalam penggunaan aplikasi sudah tercapai karena berdasarkan tabel skala opinion dan bobot diketahui bahwa sistem yang berada pada rentang nilai MOS 4 sampai dengan 5 dikelompokkan ke dalam kategori sistem good (baik).

Hasil pengujian parameter MOS yang diberikan oleh 10 orang responden masyarakat umum dapat dilihat pada Tabel XII.

TABEL XII. PENGUJIAN MOS RESPONDEN MASYARAKAT UMUM

\begin{tabular}{|c|c|c|c|c|c|c|c|c|}
\hline No & Pertanyaan & $\begin{array}{l}\text { SS } \\
(5)\end{array}$ & $\begin{array}{l}S \\
(4)\end{array}$ & $\begin{array}{l}\text { TT } \\
\text { (3) }\end{array}$ & $\begin{array}{l}\text { TS } \\
(2)\end{array}$ & $\begin{array}{c}\text { STS } \\
(\mathbf{1})\end{array}$ & Total & $\begin{array}{c}\text { Mean } \\
\text { pi }\end{array}$ \\
\hline 1 & Pertanyaan 1 & 5 & 5 & - & - & - & 10 & 4.5 \\
\hline 2 & Pertanyaan 2 & 7 & 3 & - & - & - & 10 & 4.7 \\
\hline 3 & Pertanyaan 3 & 5 & 5 & - & - & - & 10 & 4.5 \\
\hline 4 & Pertanyaan 4 & 7 & 3 & - & - & - & 10 & 4.7 \\
\hline 5 & Pertanyaan 5 & 4 & 4 & 2 & - & - & 10 & 4.2 \\
\hline \multirow{2}{*}{\multicolumn{8}{|c|}{\begin{tabular}{|c|c|c|c}
2 & - & - & 50 \\
\multicolumn{3}{c|}{ MOS (Mean Opinion Score) } \\
\end{tabular}}} & 22.6 \\
\hline & & & & & & & & 4.52 \\
\hline
\end{tabular}




\section{Keterangan:}

Pertanyaan 1:

Tampilan sistem pakar diagnosa kelainan tulang ini menarik dan mudah digunakan (user friendly)

Pertanyaan 2: $\quad$ Informasi gejala dan penyakit yang ditampilkan mudah dimengerti

Pertanyaan 3: $\quad$ Sistem pakar ini dapat memberikan informasi saran pencegahan kelainan tulang

Pertanyaan 4: $\quad$ Sitem pakar ini dapat menambah pengetahuan masyarakat serta membantu masyarakat melakukan diagnosa kelainan tulang menjadi lebih mudah

Pertanyaan 5: Pada waktu mendatang anda akan menggunakan sistem ini untuk melakukan konsultasi kelainan tulang apabila sewaktu-waktu gejala dirasakan

Berdasarkan Tabel XII dapat dilihat bahwa diperoleh hasil perhitungan nilai akhir MOS sebesar 4.52. Berdasarkan nilai tersebut dapat disimpulkan tujuan pengujian MOS oleh masyarakat umum untuk mengetahui kelayakan sistem dari sisi kemudahan penggunaan aplikasi dan memahami informasi yang ditampilkan sudah tercapai karena berdasarkan tabel skala opinion dan bobot diketahui bahwa sistem yang berada pada rentang nilai MOS 4 sampai dengan 5 dikelompokkan ke dalam kategori sistem good (baik).

Berdasarkan hasil pengujian MOS pada Tabel IX, Tabel X, Tabel XI dan Tabel XII yang diperoleh dari hasil kuesioner 30 orang responden didapatkan nilai rata-rata MOS sebesar 4.45. Berdasarkan nilai tersebut dapat disimpulkan bahwa kualitas sistem pakar diagnosa kelainan tulang pada manusia dengan metode forward chaining dan Dempster Shafer dari sisi tampilan atau user inetrface dan user experience serta informasi yang ditampilkan sudah baik dan dapat dikatakan sistem sudah layak digunakan. Pernyataan hasil kualitas sistem ini berdasarkan pada tabel skala opinion dan bobot dimana pada tabel tersebut diketahui bahwa sistem yang berada pada rentang nilai MOS 4 sampai dengan 5 dikelompokkan ke dalam kategori sistem good (baik).

\section{KESIMPULAN DAN SARAN}

Berdasarkan hasil pengujian akurasi dengan 30 contoh kasus yang disajikan pada 3 orang pakar, diperoleh akurasi berdasarkan bobot rata-rata pakar sebesar $81.11 \%$, berdasarkan bobot masing-masing pakar secara berurutan sebesar $80.00 \%$ untuk pakar $1,83.33 \%$ untuk pakar 2 dan $73.33 \%$ untuk pakar 3, dimana nilai akurasi ini menunjukkan bahwa performa dari metode dempster shafer dalam mendiagnosa kelainan ortopedi sudah baik dan dapat dikatakan metode dempster shafer cocok diterapkan pada kasus kelainan ortopedi.

Berdasarkan hasil pengujian MOS (Mean Opinion Score) diperoleh nilai MOS rata-rata dari 4 kelompok responden sebesar $44.45 \%$ dari skala 5 yang menunjukkan bahwa sistem layak digunakan dan dikategorikan ke dalam sistem yang baik (good)

Penelitian ini dapat dikembangkan dengan menambah jumlah data penyakit dan gejala dan jika memungkinkan mencakup semua jenis kelainan ortopedi sebagaimana tercantum pada buku panduan ortopedi untuk menambah informasi yang disampaikan kepada masyarakat serta untuk mengetahui unjuk kerja metode dempster shafer ketika dilakukan penambahan data, apakah berpengaruh atau tidak.

Selain itu juga perlu dilakukan penelitian dengan menggunakan mesin inferensi serta metode sistem pakar lainnya sehingga dapat membandingkan metode mana yang lebih baik dan akurat untuk diterapkan dalam kasus kelainan sistem ortopedi ini. Sistem yang dikembangkan berbasis online dan bersifat dinamis, dalam artian terdapat proses sinkronisasi data dengan perangkat lain sehingga dapat diterapkan di puskesmas atau rumah sakit dan memungkinkan untuk adanya pembaharuan data ketika terdapat keluhan baru dari pasien.

\section{DAFTAR PUSTAKA}

[1] A. Herliana, V. A. Setiawan, and R. T. Prasetio, "Penerapan Inferensi Backward Chaining Pada Sistem Pakar Diagnosa Awal Penyakit Tulang," J. Inform., vol. 5, no. 1, pp. 50-60, 2018.

[2] "Apa itu Konsultasi Ortopedi: Gambaran Umum, Manfaat, dan Hasil yang Diharapkan," docdoc, 2016. https://www.docdoc.com/id/info/procedure/konsultasimengenai-tulang/ (accessed Apr. 11, 2020).

[3] D. R. Herfian and K. Hernawati, "Sistem Pakar Untuk Mendiagnosis Penyakit Tulang, Sendi dan Otot (TSO) Pada Manusia Berbasis Web," J. Mat., vol. 6, no. 2, pp. 19-32, 2017.

[4] D. Hastari and F. Bimantoro, "Sistem Pakar untuk Mendiagnosis Gangguan Mental Anak Menggunakan Metode Dempster Shafer," J-Cosine, vol. 2, no. 2, pp. 7179, 2018

[5] I. Akil, "Analisa Efektifitas Metode Forward Chaining dan Backward Chaining pada Sistem Pakar," Pilar Nusa Mandiri, vol. 13, no. 1, pp. 35-42, 2017.

[6] A. A. T. Yulianto, "Penerapan Metode Teorema Bayes pada Sistem Pakar untuk Mendiagnosa Penyakit Tulang Manusia,” Dok. Karya Ilm., pp. 0-1, 2016.

[7] K. Sukmawati and A. Pujiyanta, "Deteksi Penyakit Tulang Menggunakan Jaringan Syaraf Tiruan dengan Metode Backpropagation," J. Sarj. Tek. Inform., vol. 2, pp. 13081321,2014

[8] M. P. Sari and Realize, "Sistem Pakar Mendiagnosa Penyakit Osteoporosis Pada Lansia Menggunakan Metode Forward Chaining Berbasis Web," J. Ilm. Inform., vol. 01, no. $1,2019$.

[9] S. Halim and S. Hansun, "Penerapan Metode Certainty Factor dalam Sistem Pakar Pendeteksi Resiko Osteoporosis dan Osteoarthritis," Ultim. Comput., vol. VII, no. 2, pp. 5969, 2015.

[10] R. Setiawan, C. Suhery, and S. Bahri, "Implementasi Metode Dempster Shafer Pada Sistem Pakar Diagnosa Infeksi Penyakit Tropis Berbasis Web," J. Coding, vol. 06, no. 03, pp. 97-106, 2018.

[11] S. Maulana, N. Hidayat, and E. Santoso, "Implementasi 
Metode Dempster Shafer Dalam Diagnosis Penyakit Pada Tanaman Jeruk," J. Pengemb. Teknol. Inf. dan Ilmu Komput., vol. 1, no. 12, 2017.

[12] F. Ikorasak, "Sistem Pakar Mendiagnosa Penyakit pada Tulang dengan Menggunakan Metode Certainty Factor,' Semin. Nas. Inform., pp. 87-90, 2015.

[13] R. E. Sahputra and I. Munandar, "Laporan Kasus Spondilitis Tuberkulosa Cervical," J. Kesehat. Andalas, vol. 4, no. 2, pp. 639-648, 2015.

[14] F. Mahyudin, M. Edward, M. H. Basuki, Y. A. Bari, and Y. Suwandani, "Osteosarcoma Has Not Become Attention To Society Profile Of Osteosarcoma Patients At Dr. Soetomo
General Hospital Surabaya 'A Retrospective Study," JOITNS, vol. 7, no. 1, 2018.

[15] P. G. T. Gustandra, "Osteokondroma Ulna Distal Dengan Deformitas Masada Tipe I Pada Anak Laki-Laki Berusia 7 Tahun: Sebuah Laporan Kasus," E-Jurnal Med. Udayana, vol. 3, no. 3, 2014

[16] A. Faturrahman, "Penatalaksanaan Fisioterapi Pada Scoliosis Vetebra Thoracal 7 - Lumbal 1 Di Rsal Dr . Ramelan," Univ. Muhammadiyah Surakarta, 2013.

[17] A. Rosana MZ, "Sistem Pakar Diagnosa Penyakit Kulit pada Manusia dengan Metode Dempster Shafer," Progr. Stud. Tek. Inform. Univ. Mataram, 2019. 